\title{
PREZENTACE NĚMECKO-ČESKÉHO UMĚNÍ VE STÁLÝCH EXPOZICÍCH NÁRODNÍ GALERIE V PRAZE
}

\author{
BARBORA PAVLIŠ FICKOVÁ \\ Katolická teologická fakulta Univerzity Karlovy \\ fickovab@gmail.com
}

\begin{abstract}
Presentation of the German-Czech Art in the Permanent Exhibitions of the National Gallery in Prague

The aim of this article is to show how the National Gallery presented the German-Czech artists and in which way it interpreted them in its presentation of national modern art. The article points out the issues of the canonisation of Czech modern art and how the politics influenced the art history and why it was so complicated to add the German-Czech artists in the Czech art history even after 1989.

Keywords: Modern art - national art - German-Czech art - National Gallery - cultural politics - narrative of history
\end{abstract}

Umění umělců, kteří se hlásili k německé národnosti a žili na území Československa, se od roku 1989 opakovaně objevuje jako téma uměleckohistorických prací, často s odkazem na to, jak opomíjení tito umělci byli v rámci českých dějin umění. ${ }^{1}$ Jako zásadní události pro tuto situaci se uvádí druhá světová válka, kolektivní vina uvalená na německé obyvatele $\mathrm{v}$ rámci Benešových dekretů, občas i celkové přerušení přirozeného vývoje po roce 1948, který se projevil nevystavováním děl těchto umělců. Tomu by odpovídal zvýšený zájem o jejich práce po roce 1989. Třicet let od sametové revoluce je ale jasné, že pokud by platilo pouze výše uvedené, díla perzekvovaných německo-českých umělců by se do kánonu českého moderního umění vrátila a nebylo by zapotřebí se o nich stále bavit jako o opomíjených. K tomu ale nedošlo. Ukazuje se, že problém není jen $\mathrm{v}$ politicko-společenské rovině nebo $\mathrm{v}$ historické paměti, ale i v rovině uměleckohistorické. Způsob prezentace českého, národního umění po roce 1945 vedl postupně $k$ tomu, že pro německo-české umění již nezbylo v kánonu místo. Postupně vytvořený narativ byl natolik silný, že zapojení dalších umělcủ, obzvláště z období moderního umění - tedy od devadesátých let 19 . století do třicátých let 20 . století - by znamenalo

1 Jednou z prvních výstav věnovaných tomuto tématu byla výstava Mezery v historii uspořádaná Galerií hlavního města Prahy v roce 1994. Téměř o 20 let později prezentovala Oblastní galerie v Liberci výstavu Mladí lvi v kleci, která byla jedním z největších projektů na toto téma. Obě výstavy zmiňovaly, jak opomíjení vystavovaní autoři byli. - Hana Rousová (ed.), Mezery v historii 1890-1938: Polemický duch střední Evropy - Němci, Židé, Češi, Praha 1994. - Anna Habánová (ed.), Mladí lvi v kleci: umělecké skupiny némecky hovořicích výtvarníků z Čech, Moravy a Slezska v meziválečném období, Revnice 2013. 
nabořit celkové vnímání dané epochy, včetně její periodizace a provázanosti konkrétních stavů. Právě způsobem, jak formování dějin českého moderního umění ovlivnilo vnímání německo-českých umělců, se zabývá tento text, a to na příkladě nejvyšší instituce, Národní galerie. Od jejího založení uspořádala Národní galerie několik souborných výstav zaměřených na souhrn českého moderního umění, které postupně vedly ke kanonizaci dějin českého moderního umění.

Národní galerie oficiálně vznikla v roce 1949. Fakticky to ale bylo pouze potvrzení již fungující reorganizace, která proběhla za války v roce 1942. Propojila se tím sbírka Moderní galerie a Obrazárny Společnosti vlasteneckých přátel. Tím zároveň došlo k velmi zajímavé situaci, protože Moderní galerie byla před válkou, stejně jako velké množství dalších institucí, rozdělena na českou a německou sekci s vlastním kuratoriem a také s vlastním rozpočtem a koncepcí sbírky. A zatímco česká sekce se zaměřovala obzvláště na díla podporující stále křehkou národní identitu a obracela se tak nejčastěji k umělcům, kteří se etablovali na přelomu století, německá sekce naopak po roce 1918 velmi intenzivně podporovala mladé německé autory. ${ }^{2}$ Obě dvě sekce zároveň pořizovaly i zahraniční akvizice. Národní galerie získala do svého majetku sbírky obou dvou těchto sekcí a tedy i velmi dobře koncipovanou sbírku německého a německo-českého umění. Sbírka německého umění ale zdaleka nebyla hlavní problém, který nově vzniklá galerie měla. Podobně jako před válkou spočíval problém v samotné prezentaci moderního umění. Galerie neměla dostatek prostor a právě moderní umění se svého vlastního paláce dočkalo až po roce 1989.

Oficiální postoj k německé kultuře na území Československa byl veřejně deklarován okamžitě po skončení války. Již 29. května 1945 svolala KSČ do Lucerny manifestaci kulturních pracovníků, na které pronesl ministr školství a osvěty Zdeněk Nejedlý projev Za lidovou a národní kulturu. V něm velmi vášnivě odsoudil vše německé jako fašistické a jako jeden $\mathrm{z}$ hlavních úkolů pro kulturní obec vytyčil defašizaci a odstranění všeho německého. O projevu referovalo Rudé právo a v následujících letech byl několikrát uveřejněn. Zdeněk Nejedlý tím nastavil směr oficiální kulturní politiky, která po roce 1948 ještě zesílila. ${ }^{3}$

Promítlo se to hned do první souhrnné výstavy moderního umění pořádané v roce 1947. Výstava nazvaná jednoduše Sbírka moderního umění proběhla v roce 1947 a prezentovala jakýsi průřez sbírkou z Národní galerie. ${ }^{4}$ Výstava byla zaměřena na české a slovenské umění, doplněno to ale bylo zahraničními díly pro kontext doby anebo vystavením obzvláště důležitých děl od významných malířu s většinovou orientací na francouzské umění, s menším důrazem pak na umění ruské. Co na této výstavě ale chybí, je německé umění. A to nejen od autorů tvořících na území Československa, ale i z Německa. Ně-

2 Jako dobrý př́klad lze uvést př́stup k dílům Bohumila Kubišty a Maxima Kopfa. Zatímco po smrti Bohumila Kubišty Moderní galerie odmítla zakoupení jeho děl nebo uspořádání výstavy, čímž si posléze zkomplikovala situaci, protože pak jeho díla získávala jen velmi složitě. Oproti tomu díla Maxima Kopfa jako velmi mladého umělce odkoupila německá sekce Moderní galerie za 14000 korun (Početí) a nebo za 4000 korun (Poutník). - Viz František Čeřovský, Život a osobnost Bohumila Kubišty ve vzpominkách současníkủ, Praha 1949. - Ivo Habán, Maxim Kopf 1892-1958: Festival Uprostřed Evropy $/$ Mitte Europa, Cheb 2002.

3 Zdeněk Nejedlý, Za lidovou a národní kulturu, in: České umění 1938-1989, Jiř̌ Ševčík - Pavlína Morganová - Dagmar Dušková (eds.), Praha 2001, s. 53-54.

4 Sbírka moderního umění (katalog výstavy), Národní galerie v Praze 1947. 
mecký expresionismus byl pravděpodobně tím proklamovaným fašistickým a německým uměním, kterého se česká kultura měla podle Zdeňka Nejedlého zbavit.

To samo by bylo z politického a společenského hlediska s ohledem na tehdejší dobu pochopitelné. Problémem ovšem bylo, že tato př́sně stanovená pravidla jednoduše neplatila pro všechny. $Z$ dnešního pohledu lze konstatovat, že nevystavování všech německo-českých umělců fungovat nikdy nemohlo, a to hned z několika důvodů. Prvním bylo, že se stále jednalo o díla z velmi nedávné doby. Většina autorů byla stále naživu a někteří dokonce i žili v Československu, protože se jich z různých důvodů netýkal odsun, čímž zároveň většinou získali české občanství. Někteří se pak postupně i přes různé obtíže zapojili zpět do uměleckého života. Druhým bylo, že určit národnost mnoha umělců zdaleka nebylo tak jednoduché. ${ }^{5} \mathrm{~V}$ případě německo-českých umělců by se dala vzít v potaz např́íklad jejich příslušnost k uměleckým skupinám, které byly povětšinou národnostně rozdělené. Ovšem ani toto dělení nebylo úplně striktní a někteří autoři se i tak ocitali na pomezí. Překvapivý v tomto ohledu je vztah české historiografie umění k židovským umělcům. Logicky by se na ně defašizace českého umění neměla vztahovat, ale bohužel tomu tak úplně vždy nebylo. Téměř by se dalo říct, že se to využívalo dle potřeby. Posledním důvodem pak bylo, že německá komunita žila povětšinou v pohraničních oblastech, kde opravdu vytvářela svébytnou kulturu, včetně výtvarných spolků a výstavního programu. Ve větších městech byla ale situace mnohem složitější a vztahy mezi jednotlivými umělci provázanější, obzvláště ve chvíli, kdy se jednalo o vystavování v zahraničí.

Na výstavě z roku 1947 se vyskytují hned tři umělci, kteří byli před rokem 1938 označováni jako němečtí, byli př́slušníci německých výtvarných skupin, př́ípadně studovali nebo vyučovali na německé části Akademie výtvarných umění - Willi Nowak, Alfred Justitz a Georges Kars. Jejich zařazení naznačuje, jakým směrem se české dějiny umění ve vztahu k německo-českým umělcům touto výstavou vydávají. Justitz i Kars se totiž na konci třicátých let stali členy SVU Mánes. Kars sice trávil většinu svého života v zahraničí, ale ve Francii a později ve frankofonní části Švýcarska, což umožňovalo napojit ho na narativ o propojení českého a francouzského umění, který českým dějinám umění dominoval. Kars byl navíc z židovské rodiny. S jeho osudem se pojil tragický příběh, kdy po skončení války spáchal sebevraždu, když zjistil, že většina jeho rodiny zahynula. Jaká konkrétní informace vedla k tomu, že zde byl zastoupen, nelze z textu ani z jiných materiálů zjistit. Mohla to být také kombinace všeho výše zmíněného.

Třetí umělec, Willi Nowak, je v tomto ohledu velmi zajímavou postavou. Po roce 1945 vstoupil do KSČ a v roce 1957 získal titul zasloužilého umělce, oboje samozřejmě jeho vnímání mohlo významně ovlivnit. V roce 1947 nebylo v katalogu ani zmíněno, že byl dlouhodobě profesorem na pražské Akademii, ovšem na německé části, přestože u jiných podobná informace uvedena byla. Na dalších výstavách již tato skutečnost byla zmíněna, ale často samozřejmě bez detailu, že se jednalo o německou část. V sedmdesátých letech se pak začalo mluvit o tom, že sice byl profesorem na německé části, ale vždy sympatizo-

\footnotetext{
Skvělým př́íladem může být Oskar Kokoschka, který na této výstavě byl také zastoupen. Oskar Kokoschka se narodil v Rakousku-Uhersku a během svého života žil v mnoha státech nejen Evropy. Na jeho národnost si tak postupně činili nárok Rakousko, Německo ale i Československo, protože zde měl část rodiny a před útěkem $\mathrm{z}$ Evropy před druhou světovou válkou zde dlouhou dobu pobýval. Zároveň se ho některé státy zř́íkaly, když byl jeho život př́liš skandální.
} 
val s českými, slovenskými a židovskými umělci. Tato věta se pak pravidelně vyskytuje ve spojitosti s Willi Nowakem i po roce 1989, a to bez ohledu na to, že není možné tento fakt nijak doložit. Nemes pak ve své vzpomínkové knize rovnou píše, že Nowak bral primárně ne-německé studenty, a dokonce, že německé studenty se snažili se školy vyloučit. Tuto informaci ale nelze jinak doložit a dá se předpokládat, že byla spíše mýtem spojeným s postavou zcela jistě charismatického Nowaka. ${ }^{6}$

Přestože v žádném doprovodném textu se specifický odkaz na politiku defašizace českého umění neobjevil, je zřejmé, že to výstavu ovlivnilo. Způsob výběru autorů, kteří by mohli být považováni za německé, ale přesto zde byli vystaveni, byl založen spíše na politickém či společenském hledisku než na umělecké hodnotě daných děl.

Další výstava podobného charakteru se uspořádala až po dvanácti letech, v roce $1959 .{ }^{7}$ $\mathrm{Z}$ úvodního textu je zřejmé, že tato výstava byla výrazně ovlivněna soudobou rétorikou. Krátký text od Jiřího Šetlíka zdůrazňuje třídní boj, význam dělníků a rolníků a také důraz na národní aspekty moderního umění. Ty autor nacházel hlavně u Rabase, Sedláčka a Rady. V návaznosti na německo-české umělce se zde pouze neadresně zmiňuje boj proti fašismu a za nový sociální řád. Zpřísněná rétorika se ale paradoxně promítla až do výběru nejmladších autorů, ne do interpretace doby před válkou. Na výstavě bylo zastoupeno 112 umělců a z toho 52 bylo shodných s předchozí výstavou. Valná většina ostatních byla tvořena mladšími autory, včetně děl, která byla datována do roku 1958. Předchozí výstava si oproti tomu nechávala odstup a nejmladší díla byla $\mathrm{z}$ doby před válkou. Všichni tři umělci zmínění výše byli i na této výstavě.

Zajímavé je ale porovnání této výstavy s následující, která se uskutečnila jen pouhé tři roky poté a jejíž kurátor byl taktéž Jiří Šetlík. ${ }^{8}$ Výstava s názvem České a slovenské malírství první poloviny 20. století se poprvé věnuje hlubší analýze sledovaného období. Nezaměřuje se pouze na jednotlivá jména, ale propojuje je navzájem do skupin, at již reálných (generace Osmy, Tvrdošíní), podle stylu (surrealismus), nebo podle charakteristické doby tvorby nebo historické události (nástup fašismu). Tato výstava tak přináší do vztahu k německo-českým umělcům nové prvky.

Tím prvním bylo vyzdvihnutí skupiny Osma a celkově mladé nastupující generace té doby. To ale nebyla zásluha Jiř́iho Šetlíka, ale spíše reflexe výstavy Miloslava Lamače a Jiř́ho Padrty Zakladatelé moderního malírství z roku $1957 .{ }^{9} \mathrm{Na}$ ní autoři vyzdvihli vliv německého expresionismu na české moderní umění, oproti do té doby prosazovanému francouzskému kubismu. Lamač také popsal všechny členy skupiny Osma, která byla první a prakticky jedinou moderní národnostně nehomogenní výtvarnou skupinou. Zatímco na Lamačově výstavě němečtí členové skupiny prezentováni byli, na výstavě v Národní galerii nikoli. Skupina Osma se zde ale stává zlomovým momentem českých dějin umění. Zároveň ale i zde je uvedeno, že francouzský vliv nakonec u skupiny převládl, stejně jako u celého českého umění.

Endre Nemes, Pod př́krovem času, Praha 2003, s. 57.

Sbirka moderního umění: Československé malírství 20. století (katalog výstavy), Národní galerie v Praze, 1959.

8 Jiř́ Šetlík, České a slovenské maliŕství první poloviny 20. století (katalog výstavy), Národní galerie v Praze, 1965.

9 Miloslav Lamač - Jiří Padrta, Zakladatelé moderního českého umění (katalog výstavy), Dům umění města Brna, 1957. 
Druhým momentem je velmi těsné provázání jednotlivých umělců. Šetlík zde vstupuje i mimo konkrétní skupiny a vykresluje české dějiny umění jako provázaný systém, kde nikdo nezůstává na okraji. Zatímco předchozí výstavy sledovaly spíše jednotlivé osobnosti, ve výstavě z roku 1962 se mnohem více dbá na vytváření skupin osobností, které se navzájem ovlivňovaly. Kompaktnější uchopení dějin umění pomáhá vytvářet představu lineárního vývoje, ve kterém jednotliví umělci navazují na sebe a dohromady vytváří české moderní umění.

Na této výstavě se nevyskytuje Georges Kars pravděpodobně proto, že ve skutečnosti žil v zahraničí a na výstavě byl kladen i důraz nejen na české umění jako obecný pojem, ale i na jeho geografické ukotvení. Namísto toho se zde ale objevuje sochařka Mary Duras, která sice byla před druhou světovou válkou spojena s německými výtvarnými skupinami, ale díky aktivitě za války a manželovi zůstala i po roce 1945 v Československu. Její situace na uměleckém poli sice nebyla jednoduchá, ale na začátku šedesátých let dostávala i některé veřejné zakázky. ${ }^{10}$

Lze říci, že zatímco předchozí výstavy německo-české umění ignorovaly a o čemkoli s ním spojeným se nezmiňovaly, výstava z roku 1962 si je př́tomnosti těchto umělců vědoma, ale cíleně je nezahrnuje do českých dějin umění a naopak se zaměřuje na vybudování ideálu o jasném vývoji českého moderního umění.

Význam skupiny Osma se nejvíce projevuje na další výstavě z roku 1972. ${ }^{11}$ Výstava s názvem České malírství XX. století, s podtitulem Díl II / Generace Osmy, Tvrdošíných, Umělecké besedy, ukotvila generaci Osmy jako další zlomový bod po generaci devadesátých let. V obsáhlém katalogu je od každého uvedeného autora kompletní soupis děl v majetku Národní galerie, což je neocenitelnou pomůckou pro zkoumání dané epochy. Na výstavě se kromě již klasických tří německo-českých umělců objevují i další členové skupiny Osma. Mohlo by se zdát, že by tento př́istup mohl pomoci vnímání německo-českých umělců, například prostřednictvím postavy Bedřicha Feigla, který skrze svoje kontakty podporoval české i německo-české umění v Německu. Při podrobnějším pohledu se ale ukazuje, že v soupisu výstav u jednotlivých umělců většinou chybí výstavy uskutečněné v Německu. Není to ovšem pouze tím, že by se nezveřejňovaly zahraniční výstavy, protože například u Georgese Karse jsou výstavy ve Francii vypsány všechny.

Upevňuje se zde tedy obraz toho, že v Československu, respektive v Čechách, se budovalo pouze české umění a němečtí autoři se mohli do tohoto kánonu dostat pouze v případě, že na něj byli dostatečně navázáni například pro členství v českých skupinách.

V osmdesátých letech pak Národní galerie uspořádala ještě jeden šestnáctidílný výstavní celek, který rozvržením kopíroval periodizaci použitou Jiřím Šetlíkem a od té doby již obecně přijímanou. Co je ale fascinující, spočívá ve faktu, že výstava, kterou Národní galerie uspořádala ve spolupráci s galerií v Darmstadtu, zahrnula české i německé umění dvacátých a třicátých let. ${ }^{12}$ Zde se najednou objevují umělci, kteří opravdu předchozích čtyřicet let vystavováni nebyli. Nejedná se o nějaký zázračný přístup, který by najednou představil desítky nových jmen, ale rozhodně se v tomto ohledu jedná

10 Příběh Mary Duras popsal Ivo Habán. Ivo Habán, Mary Duras, Řevnice 2014.

11 České malírství XX. století ze sbírek Národní galerie v Praze: Díl II / Generace Osmy, Tvrdošijných, Umělecké besedy (katalog výstavy), Národní galerie v Praze, 1973.

12 Bernd Krimmel - Jiří Kotalík (eds), Tschechische Kunst der 20er+30er Jahre: Avantgarde und Tradition, Darmstadt 1988. 
o nejobsáhlejší výstavu od vzniku Národní galerie. Jak jde vidět, situace se tak začala lámat ještě před rokem 1989. Po dlouhých třiceti letech vyšla také kniha Miloslava Lamače Osma a Skupina výtvarných umělců, která měla původně doplňovat výstavu z roku 1957. ${ }^{13}$ Zájem o německo-české umělce tak nebyl až tak ovlivněn změnou režimu, spíše se jednalo o postupné odkrývání dlouho opomíjeného tématu, které sametová revoluce jen urychlila.

Po roce 1989 vzniklo postupně několik výstav, které se snažily německé umělce do českého kánonu zařadit. Nejčastější cesta vedla ve stopách Miloslava Lamače přes dualitu expresionismu a kubismu. Jen některé publikace se věnovaly například fenoménu nové věcnosti nebo umělecké výměně s Německem.

V Praze převzala iniciativu v tomto směru Galerie hlavního města Prahy. Téma ale bylo podstatné i pro galerie v regionech, kde se uměleckohistorická otázka propojovala s historií konkrétního regionu. ${ }^{14}$ Samotná Národní galerie se ale potýkala s vlastními problémy ohledně identity, její role v demokracii, ale také s problémy rekonstrukce Veletržního paláce. Ta se nakonec protáhla, takže první expozice moderního umění zde byla otevřena přesně padesát let po založení Národní galerie. I přestože to bylo až v roce 1995, zdá se, že expozice reflektovala jen velmi málo z probíhajících uměleckohistorických diskuzí.

Ne úplně ideální situaci pak završila následující stálá expozice, která vznikala za ředitele Milana Knížáka. Ta cíleně zařadila německo-české umělce do zahraničního umění i přes nevoli určité části kurátorů. ${ }^{15}$

Přístup po roce 1989 jednak ukazoval obecné společenské nastavení, kdy vztah české většiny $\mathrm{k}$ německo-české komunitě zdaleka nebyl ideální a rozhodně se nedá říct, že by došlo k nějakému smíření. Také se ale ukázalo, že zařazení německo-českých umělců do českých dějin umění není jednoduché i přes velmi dobrý uměleckohistorický výzkum. Najednou se zdálo, že tyto autory není kam zařadit. Varianta vytvořit jakousi paralelní linku německo-českého umění, která nenarušovala to české, se zdála být jako jedna $\mathrm{z}$ možností. Vedla ale pouze k většímu oddělení. Pokud by se opravdu mělo německo-české umění zařadit do dějin českého umění, bylo by zapotřebí rozebrat celkově narativ českého moderního umění, který byl výše zmíněnými výstavami definován. Na to je ale zapotřebí vnímat tyto dějiny jako konstrukt vytvořený za určitých historických a politických podmínek a ne jako objektivní historický vývoj. Jedná se přitom jen o umělce, kteří se navzájem opravdu potkávali. Naprosto jinou výzvou pak je otázka sudetských umělců a jiných okrajových skupin, které se do jisté míry opravdu vyvíjely separátně od hlavního proudu.

13 Miloslav Lamač - Jiří Padrta, Osma a skupina výtvarných umělcư: 1907-1917, Praha 1988.

14 Jana A. Brabcová ed., Mezery v historii: sborník příspěvků ze sympozii Společnosti pro české a německé umění a dějiny umění, konaných v letech 2004-2009 v rámci Festivalu uprostřed Evropy - Mitte Europa $v$ Chebu, Cheb 2010.

15 České moderní a současné umèní 1890-2010 katalog stálé expozice Sbírky moderního a současného umění a Sbírky umění 19. století Národní galerie v Praze. 2. díl, Praha 2010. 


\section{SUMMARY}

\section{Presentation of the German-Czech Art in the Permanent Exhibitions of The National Gallery in Prague}

The article summarises how the National Gallery became involved in shaping the canon of Czech modern art with an emphasis on the relationship to German-Czech artists. After the establishment of the National Gallery, the institution received all the artworks from the former Modern gallery including the German and German-Czech art collection. But most of the artworks have never left the depositary. The text analyses all the permanent exhibitions of modern art organised by the National Gallery and describes how these exhibitions approached the issue of German-Czech art. The main focus is on exhibitions organised between 1945 and 1989 because at this time the approach to the art of the first half of the 20th century was codified. The understanding of the process of codification and how it was influenced by the contemporary view of the historical situation can help to understand why, even 30 years after the Velvet Revolution, it is difficult to involve German-Czech culture in Czech culture. It turns out, that the opinions about fascist german and German-Czech art, which were clearly stated after WWII, have never been fulfilled. Although in the beginning it could be said, that the reason for the absence of these artists was historical and influenced by WWII, in the long term the reason was rather nationalist and influenced by the specific art-historical approach to the Czech modern art. That means for example searching connections among all the Czech artists and creating a network of influence between them, without respect to the existing art groups and societies. Once this network was codified, it became difficult to add any names from the outside of the codification. The main reason why is it so hard to put German-Czech artists in the canon of Czech modern art is not about any gap, that could be filled. It is more about rewriting the whole Czech art history with new names and new networks.

\section{VÝBĚROVÁ BIBLIOGRAFIE}

Milena Bartlová - Jindřich Vybíral (eds.), Budování státu: reprezentace Československa v umění, architektuře a designu, Praha 2015.

Hana Rousová (ed.), Mezery v historii 1890-1938: Polemický duch střední Evropy - Němci, Židé, Češi, Praha 1994.

Anna Habánová - Ivo Habán (eds.), Ztracená generace?: Německočeští výtvarní umělci 1. poloviny 20. století mezi Prahou, Vídní, Mnichovem a Drážd’any, Liberec 2013.

Ondřej Jakubec - Radka Nokkala Miltová (eds.), Umění a politika: Sborník 4. sjezdu historiků umění, Brno 2013.

Ivo Habán, Maxim Kopf 1892-1958: Festival Uprostřed Evropy / Mitte Europa, Cheb 2002.

Bernd Krimmel - Jiří Kotalík (eds.), Tschechische Kunst der 20er+30er Jahre: Avantgarde und Tradition, Darmstadt 1988.

Anna Habánová (ed.), Mladí lvi v kleci: umělecké skupiny německy hovořicích výtvarníků z Čech, Moravy a Slezska v meziválečném období, Řevnice 2013.

Jiří Ševčík - Pavlína Morganová - Dagmar Dušková (eds.), České umění 1938-1989 : programy, kritické texty, dokumenty, Praha 2001.

Miloslav Lamač - Jiří Padrta, Osma a skupina výtvarných umělců: 1907-1917, Praha 1988. 